\title{
A madridi rezidentúra - A magyar hírszerzés Spanyolországban a detente csúcspontjától a kishidegháború végéig, 1976-1984
}

\begin{abstract}
Nem sokkal azt követően, hogy a Magyar Népköztársaság (MNK) és a Spanyol Királyság közvetlenül az enyhülés folyamatának csúcspontját követően felvette a diplomáciai kapcsolatokat, a madridi magyar nagykövetségen egy hivatásos biztonsági tisztből és az alárendeltségében álló titkos munkatársakból álló hírszerzőpont létesült. A rezidentúra mindenekelött a külképviseleti szervek operatív védelmére koncentrált, ugyanakkor, jelen ismereteink szerint nem sok sikerrel, próbálkozott a vezető NATO-tagállamok ellen irányuló hírszerzéssel.
\end{abstract}

Kulcsszavak: hírszerzés harmadik országos bázison, követségi elhárítás, NATO

\begin{abstract}
Pál István: The Madrid Residency.
The Hungarian Intelligence Service in Spain from the peak of détente to the end of the Little Cold War, 1976-1984

Shortly after the culmination of the détente the Hungarian People's Republic and the Kingdom of Spain had established diplomatic relations and an intelligence section consisting of a commissioned officer and half a dozen co-optees came to existence at the Hungarian Embassy in Madrid. The so-called residency was concentrating on the protection of the foreign representations of Hungary, but at the same time, it endeavored to carry out operations against the leading NATO-powers on a thirdcountry basis. Based on our present knowledge, these experiments were taking place without proper success.
\end{abstract}

Keywords: intelligence based on a third country, counterintelligence among embassy personnel, NATO

\section{Az előzmények}

A magyar-spanyol diplomáciai kapcsolat első felvételére csak az I. világháború után, az Osztrák-Magyar Monarchia felbomlásának idején került sor. A viszony sokáig aszimmetrikus maradt, amennyiben hazánk érdekeit éveken át a párizsi magyar követség képviselte, a madridi misszió csak 1927-től müködött. ${ }^{2}$ A spanyol belpolitikai élet bizonytalanságai, majd a polgárháború visszavetette az érintkezést, igaz, Horthy Miklós

Pál István, az ELTE BTK egyetemi adjunktusa, e-mail: stevepal@freemail.hu

Anderle Ádám: Bevezetés. A magyar-spanyol diplomáciai kapcsolatok történetéhez. Külügyi Szemle, 9. (2010), 3. 5-6. 
kormányzó 1938 elején elismerésben részesítette a Franco-rendszert. ${ }^{3}$ 1945. május 7-én a spanyol kormány felszólítására a követségnek be kellett szüntetnie minden addig tevékenységet, azonban Marossy Ferenc, korábbi helsinki követ a Magyar Nemzeti Bizottmány képviseletében 1948 után egészen 1969-ig fenntartotta a Magyar Királyi Követség müködését. ${ }^{4} \mathrm{~A}$ kétoldalú viszony rendezésének többek között ez volt az egyik legfontosabb gyakorlati akadálya, ugyanakkor a keleti blokkban nagyon sokáig azt az álláspontot képviselték, hogy Franco tábornok életében nem fognak diplomáciai kapcsolatokat létesíteni Spanyolországgal. Az egységes fellépést az „örök renitens” Románia törte meg 1967-ben, majd 1973-ban a Német Demokratikus Köztársaság (NDK) is rászánta magát a döntő lépésre. Magyarország végül csak a Szovjetunióval egy időben, 1976 folyamán állította helyre a diplomáciai kapcsolatokat a Spanyol Királysággal. ${ }^{5}$

\section{A rezidentúra megalakulása és múködési keretei}

Miután 1977 januárjában megnyílt a Magyar Népköztársaság madridi nagykövetsége, ${ }^{6}$ a Belügyminisztérium (BM) III/I. (Hírszerző) Csoportfönökség a madridi magyar nagykövetségen is hírszerzőpontot létesített. 1979-től Juhász Péter (fedőneve „Jászai”) lett a nagykövetség biztonsági felelőseként a rezidens, míg az elektronikus védelmi rendszerek üzemeltetése Horváth Sándor (fedőneve „Duba”) ${ }^{7}$ biztonságtechnikai felelős hatáskörébe tartozott. A III/I-4-es Osztályról, amely 1976 és 1980 között a NATO-val és Dél-Európával foglalkozott, ${ }^{8}$ Kósa György alezredes (fedőneve „Dér”) volt a madridi rezidentúra felelőse. ${ }^{9}$ A rezidentúra müködésében két utasítás volt mérvadó. A III/I-2-es Osztály, amely 1971-től 1990-ig a külképviseletek biztonságért és a támadólagos elhárításért - az ellenséges hírszerző és elhárító szervekkel szemben kezdeményezett műveletekér ${ }^{10}$ - volt felelös, ${ }^{11} 1979$ júliusában a madridi magyar nagykövetségen dolgozó és a kereskedelmi kirendeltséghez rendelt titkos munkatársaktól az amerikai és a nyugatnémet diplomatakapcsolataik felsorolását várta, párhuzamosan az Amerikai Egyesült Államok (USA) és az NSZK spanyolországi képviseleteiről (nagykövetség, gazdasági-kereskedelmi kirendeltség, kulturális intézet, katonai küldöttség) szóló jelentésekkel. Spanyolországot az USA és a Német Szövetségi Köztársaság elleni hírszerzéshez - szakszóval harmadik országos bázis gyanánt - próbálta felhasználni

Matilde Eiroa: A múltbeli kapcsolatoktól a jelenkori követelményekig. A spanyol-magyar kapcsolatok helyreállításának folyamata. Múltunk, 21. (2009), 1. 89-90.

Anderle (2010) i. m. 9.

M. Szebeni Géza: A magyar-spanyol diplomáciai kapcsolatok újrakötése. Grotius, 5. (2011), 1. 1-8.

Eiroa (2009) i. m. 96-98.

Állambiztonsági Szolgálatok Történeti Levéltára (ÁBTL) - 3. 2. 1 - Bt - 1184 - „Duba” (Horváth Sándor). - Évkör: 1960-1982.

8 Tóth Eszter: A politikai és gazdasági hírszerzés szervezettörténete 1945-1990. In Cseh Gergő Bendegúz - Okváth Imre (szerk.): A megtorlás szervezete. A politikai rendörség újjászervezése és müködése 1956-1962. Budapest, Állambiztonsági Szolgálatok Történeti Levéltára - L'Harmattan, 2013. 432-433.

9 Állambiztonsági Szolgálatok Történeti Levéltára (ÁBTL) - 3. 2. 5 - O - 8 - 562/1/2 - 15 - OD - 4896 - „Mediterrán" - Spanyolországi Magyar Kolónia Op. Védelme - Tárgy: Madridi külképviseletünkkel kapcsolatos megbeszélés. - Feljegyzés. Budapest, 1979. IX. 12. 31-32/53.

10 Állambiztonsági Értelmezö Kéziszótár. BM Könyvkiadó, Budapest, 1970. 89.

11 Tóth (2013) i. m. 427. 
a III/I. Csoportfönökség. ${ }^{12} 1980$ öszén - háromnegyed évvel az afganisztáni szovjet bevonulást követően ${ }^{13}$ - viszont a kolónia és az ott fellelhető szolgálati és államtitkok védelmére helyeződött a hangsúly. A budapesti Központ (III/I. [Hírszerző] Csoportfönökség) ezzel párhuzamosan célul tűzte ki az ellenséges speciális szolgálatokba vagy legalábbis az általuk fenntartott hálózatba történő behatolást. A szóba jöhető, külföldi állampolgárságú személyek közül az első helyen az utánpótlás-bázisként szolgáló rendőri szervek alkalmazottai, életpályájukon megrekedt, erkölcsi, politikai, anyagi okokból elégedetlen hivatásos elhárítók és hírszerzők, a külképviseletek megnyerhető vagy visszafordítható idegen állampolgárságú alkalmazottainak köre szerepelt. A második helyen a perspektivikus jelöltekre - felsőfokú tanintézetek hallgatói, fiatal oktatói, kutatói - irányult volna a figyelem. Ezzel egy időben a hírszerzőpont megfelelően felkészült hálózati személyei köréből is ki kellett jelölni azokat, akik ügynöki játszmára alkalmazhatók. Az utóbbi főleg a kolónia tagjai ellen irányuló, kompromittálási és beszervezési próbálkozások kivédésére szolgált. ${ }^{14}$ A valóságban diplomáciai körökből egyetlen titkos munkatársnak sem sikerült kapcsolatokat találni, még „Dániel” - Decker Gyula, az új kereskedelmi kirendeltségvezeto" ${ }^{15}$ - is csak a spanyol külügyminisztérium gazdaságpolitikai igazgatóságának vezetőjét és területi referensét ismerte. ${ }^{16}$ Juhász 1982 szeptemberében történt beszámoltatásakor Horváth Rezső rendőr föhadnagy kénytelen volt megállapítani, hogy a 2-es vonal (követségi elhárítás) nem rendelkezik hálózattal, e téren semmiféle előrelépés nem történt. ${ }^{17}$ 1983-ban Markó József (fedőneve „Csiki”) lett az új biztonsági felelős, ${ }^{18}$ ám a Spanyolországban tartózkodó amerikai és nyugatnémet állampolgárok megközelítése terén ő sem tudott eredményt felmutatni. Igaz, a rezidentúra energiáit lekötötték a volt sajtóattaséval összefüggésben lévő operatív kérdések, azonban ez utóbbi ismertetésétől mind terjedelmi, mind jogi okok miatt kénytelenek vagyunk eltekinteni.

\section{A Magyar Népköztársaság (MNK) kereskedelmi képviselete 1976-ban}

A MNK 1970 óta müködő madridi külképviseleti intézményei biztonsági helyzetéről 1976. november 16-án készült az első jelentés, amely a nem azonosítható, Kiskovács

12 ÁBTL - 3. 2. 5 - O - 8 - 562/1 - 15 - OD - 4896 - „Mediterrán” - Spanyolországi Magyar Kolónia Op. Védelme - 1/1-2/79. sz. Utasítás! - Jászai Elvtársnak! Madrid. - Tárgy: A hírszerzőpontok 2-es Vonal támadólagos munkájával kapcsolatos feladatok. - Budapest, 1979. VII. 13. 113-114.

13 Fischer Ferenc: A megosztott világ. A Kelet-Nyugat, Észak-Dél nemzetközi kapcsolatok fö vonásai. (1941-1991). Budapest, IKVA, 1993. 379-395.

14 ÁBTL - 3. 2. 5 - O - 8 - 562/1 - 15 - OD - 4896 - „Mediterrán” - Spanyolországi Magyar Kolónia Op. Védelme - 2/1-2/80. sz. Utasítás! - Jászai Elvtársnak! Madrid. - Tárgy: A hírszerzőpontok 2-es vonalon folytatott tevékenységének felmérése, a speciális szolgálatok elleni munka erősítésének feladatai. - Budapest, 1980. IX. 16. 23-26.

15 ÁBTL - 3. 2. 5 - O - 8 - 562/1 - 15 - OD - 4896 - „Mediterrán” - Spanyolországi Magyar Kolónia Op. Védelme - 2/2-2/1980. sz. jelentés melléklete. - Madrid, 1980. II. 15. 40.

16 ÁBTL - 3. 2. 5 - O - 8 - 562/1 - 15 - OD - 4896 - „Mediterrán” - Spanyolországi Magyar Kolónia Op. Védelme - 7/2-2/1981. sz. jelentés. - Mecseki Elvtársnak Budapest - Tárgy: diplomata kapcsolatok. - Madrid, 1981. V. 20. 67.

17 ÁBTL - 3. 2. 5 - O - 8 - 562/1 - 15 - OD - 4896 - „Mediterrán” - Spanyolországi Magyar Kolónia Op. Védelme - Belügyminisztérium III/I-2. Osztály - Tárgy: Juhász Péter elvtárs beszámoltatásáról - Jelentés. Budapest, 1982. IX. 15. 143.

18 ÁBTL - 3. 2. 5 - O - 8 - 562/1 - 15 - OD - 4896 - „Mediterrán” - Spanyolországi Magyar Kolónia Op. Védelme - Belügyminisztérium III/I. Csoportfönökség 4. Osztály. - Tárgy: Madridi és lisszaboni nagykövetségen végrehajtott technikai elhárításról. JELENTÉS. Budapest, 1983. X. 14. 196-200. 
fedőnevű titkos munkatárstól december 2-án érkezett a budapesti központba. ${ }^{19} \mathrm{~A}$ beszámoló szerint a szocialista országok állampolgárairól a spanyol hatóságok nem vezettek külön nyilvántartást, emiatt senkit sem zaklattak. A diplomáciai beosztottakkal szemben sem volt külön eljárás, amely eltért volna a többi beutazóval szembeni gyakorlattól. Az ország területén korlátozás nélkül mozoghattak, külön ellenőrzést, megfigyelést vagy provokációt a magyar konzulátus és a kereskedelmi kirendeltség személyzete nem tapasztalt. ${ }^{20} \mathrm{~A}$ spanyolországi magyar emigráció döntő többsége nem jelentett érdemi veszélyt, mivel elhatárolódott a politikától, aki e körből hazalátogatott, az valósághű képet festett az ismeretségi körében. Igaz, Endrődy Kálmán egykori katonatiszt és Pongrácz Gergely - a Corvin-közi felkelők parancsnoka - irányításával egy kifejezetten ellenséges csoport is müködött. Endrödy és Pongrácz foglalkozott azokkal a magyar állampolgárokkal, akik a külföldön maradás mellett döntöttek. A jelentkezőket alaposan kifaggatták, majd ellenszolgáltatásként vagy készpénzzel, vagy a szükséges tartózkodási és munkavállalási engedély megszerzésével, vagy éppen a továbbutazás megszervezésével segítettek. A büncselekmény áldozatául esett magyar turistáknak a madridi rendőrkapitányságon Endrődy volt a kirendelt tolmács, azonban nem a tárgyhoz tartozó kérdésekkel nem szokott elöállni. ${ }^{21}$ A MNK kereskedelmi kirendeltsége a dr. Fleming 55. szám alatt, a konzulátus pedig az Angel de Diego Roldan 21. szám alatt, utóbbi egy önálló villában nyert elhelyezést. A szomszédokkal nem tartott kapcsolatot, de ők sem keresték a magyar külképviseleti szerv dolgozóinak társaságát. Perczel László (1923-1989)22 volt ekkor a kirendeltség vezetője, Kristóf István a konzulátus titkára, Basa János a rejtjelező, Fehér József a gépkocsivezető, a felesége, Szalai Teréz (fedőneve „Edina”) ${ }^{23}$ pedig az adminisztrátor. Az épület földszintjén lévő előtérből a konzuli váróba vezetett az út, ahonnan a fogadószoba és a konzul irodája nyílt. A telefonközpont is ugyanitt müködött. A bejárati ajtót biztonsági zár védte, amit éjszakára két acélrúddal is megerösítettek, a telefonközpont bejárata a riasztóberendezésre volt kapcsolva. Az első emeleten volt a szalon, a reprezentációs ebédlő és konyha a hozzácsatolt raktárral, valamint Perczel dolgozószobája. Az ablakra itt még nem került rács, a lépcsőházi ajtókra azonban itt is biztonsági zárakat szereltek. Az ügyeleti és biztonsági helyiség a második emeleten volt, ahogy Kristóf és Basa lakása, míg Perczel Lászlóé a harmadikon, az adminisztratív irattár mellett. A negyedik emeleten a Fehér házaspár élt, ezenkívül itt alakítottak ki egy futárszobát és a felvonó gépháza is ezen a szinten müködött. Igaz, a titkos munkatárs úgy vélte, hogy csak biztonsági helyiség véd az illetéktelen és erőszakos behatolástól. Az ügyeletet a biztonsági felelős adta, akit szabadnapjain a diplomaták és a kereskedelmi kirendeltség dolgozói helyettesítettek. A biztonsági helyiségben található összes szekrény,

19 ÁBTL - 3. 2.5 - O - 8 - 562/1/2 - 15 - OD - 4896 - „Mediterrán” - Spanyolországi Magyar Kolónia Op. Védelme - Belügyminisztérium III/I-11 Osztály - 67/81-1681/76 - Budapest, 1976. XII. 2. 13.

20 ÁBTL - 3. 2. 5 - O - 8 - 562/1/2 - 15 - OD - 4896 - „Mediterrán” - Spanyolországi Magyar Kolónia Op. Védelme - 1/9/1976. 11-nek: Információs jelentés. - Tárgy: A fogadó ország titkosszolgálati szerveinek ellenőrzési módszereiről és a külképviselet biztonsági helyzetéről. - Madrid, 1976. XII. 16. 14.

21 ÁBTL - 3. 2.5 - O - 8 - 562/1/2 - 15 - OD - 4896 - „Mediterrán” - Spanyolországi Magyar Kolónia Op. Védelme - 1/9/1976. 11-nek: Információs jelentés. - Tárgy: A fogadó ország titkosszolgálati szerveinek ellenőrzési módszereiről és a külképviselet biztonsági helyzetéről. - Madrid, 1976. XII. 16. 15-16.

22 Baráth Magdolna - Gecsényi Lajos (szerk.): Főkonzulok, követek és nagykövetek. Budapest, MTA Bölcsészettudományi Kutatóközpont Történettudományi Intézet, 2015. 240.

23 ÁBTL - 3. 2. 1 - Bt - 1792/1 - „Edina” (Fehér Józsefné Szalai Teréz) - Évkör: 1975-1979. 
a széf és a bejárati ajtó ugyancsak össze volt kötve a riasztóval. A konzulátusnak egyetlen helyi alkalmazottja volt az akkor 27 esztendős Ana Luisa Alonso Castrillo de Roca személyében, aki egy amerikai érdekeltségű vegyipari cégtől igazolt át az MNK konzulátusára. A döntésében nem az anyagi szempontok játszották a fö szerepet, hanem lakóhelyének közelisége, a kedvező munkaidő-beosztás és munkahelyi légkör volt a legfontosabb. A titkos munkatárs egyben azt is sugallta, hogy a fiatalasszony és férje, Fausto Roca, részidős zenetanár egyaránt baloldali gondolkodású: emiatt a szüleivel sokszor került sor politikai vitára. Megbízhatóságával szemben nem merült fel kifogás, gyanús kérdésekkel soha nem jött elő. A kereskedelmi kirendeltségen három spanyol állampolgár állt alkalmazásban. Az 1951-es születésű Pilár Gomez-Centurion Jimenez 1973 óta végezte a titkárnői feladatokat. A fiatalasszony eredetileg újságíró volt, akárcsak férje, Ignacio Sanchez Detajada. A képviselet ügyei iránt gyanús érdeklődést nem mutatott, ugyanakkor nem is politizált. Angel Mendez Alvarez, az akkor 56 esztendős gépkocsivezető - másodállásban ékszerüzlet-tulajdonos - a kirendeltség megnyitása óta náluk dolgozott. A titkos munkatárs szerint Alvarez lojális volt a spanyolországi rendszerhez, még ha időnként akadt is egykét bíráló megjegyzése. Indokolatlan érdeklődést nem tanúsított, részéröl ügynökgyanús tevékenységgel nem találkoztak. Damiana Lozao Garciát, az akkor 56 éves takarítónőt egyszerü, jóindulatú asszonyként ábrázolta, aki nehéz helyzetbe került, mert férje évek óta munkanélküli segélyen élt. A kiküldetésben lévőket provokáció nem érte, az egymás közötti viszony baráti jelleget öltött, helytelen magatartásra vagy meg nem engedhető tevékenységre semmi sem utalt. ${ }^{24}$

\section{A nagykövetség biztonsági helyzete az évtized fordulóján}

Az MNK nagykövetségének teljes körü védelmi rendszere csak 1979. december 15-én vált üzemképessé. A biztonsági körlet védelmére az RK-10-es jelzőberendezés szolgált, míg a vagyonvédelmet az RK-04-es riasztóközpont garantálta. A konzuli irodában, a konzuli kisfogadóban, a nagykövetség bejárati halljában és a titkárságon egyaránt volt egy kapcsoló, amely vészhelyzet esetén müködésbe hozta a szirénát. A titkos beszélgetésekhez a BEBI- - Beszédbiztosító - rendszert használták, azonban a szigorúan titkos anyagokat villanyírógépen írta le a titkárnő. A BM ugyan felhívta a figyelmet arra, hogy a korszerü technika jóvoltából a spanyol elhárítás rögzítheti és dekódolhatja a villanyírógéppel írt szövegeket, a Külügyminisztérium (KÜM) nem törödött a figyelmeztetéssel. Kincses László - 1979 és 1983 között nagykövet ${ }^{25}$ - sem rajongott a BEBI használatának gondolatáért, így Juhász Péternek komoly erőfeszítésébe került, hogy fönökét rávegye az óvintézkedés betartására. A kereskedelmi kirendeltség egy tízemeletes bérház harmadik emeleti három szoba hallos lakásában müködött, ezért a bizalmas iratokat a nagykövetség biztonsági körletében tárolták. A minősített anyagok kezelésére Éliás István kereskedelmi titkár és Mészáros Lajosné szerződéses ügykezelő - a Medimpex képviselő felesége - volt jogosult, ezeket csak

\footnotetext{
24 ÁBTL - 3. 2.5 - O - 8 - 562/1/2 - 15 - OD - 4896 - „Mediterrán” - Spanyolországi Magyar Kolónia Op. Védelme - 1/9/1976. 11-nek: Információs jelentés. - Tárgy: A fogadó ország titkosszolgálati szerveinek ellenőrzési módszereiről és a külképviselet biztonsági helyzetéröl. - Madrid, 1976. XII. 16. 18-22.

25 Baráth-Gecsényi (2015) i. m. 200.
} 
helyben olvasásra lehetett megtekinteni. A biztonsági és a biztonságtechnikai felelősön kívül a nagykövetség épületében lakott Dalmadi György gépkocsivezető és Jankovics János hivatalsegéd, ám ez önmagában még nem szavatolta az erőszakos behatolás vagy rajtaütés elleni védelmet. A nagykövetség Madrid egyik villanegyedében helyezkedett el, ráadásul a bejárati ajtó elé sem lehetett kilátni. A beosztottaknak négy személyi fegyver és egy géppisztoly állt rendelkezésére. Mindazonáltal, Juhász nem tartotta valószínűnek, hogy támadásra kerülne sor, mivel az jelentősen csorbította volna a fogadó ország tekintélyét. A titkos behatolás megakadályozására az új védelmi rendszer megfelelőnek tűnt, ugyanakkor a rendszabályok megsértésére sem került sor. A spanyol alkalmazottakat Ana Castrillo kivételével leépítették, ám az ő mozgástere a konzuli váró mellett lévő irodára korlátozódott. A nagykövetségi telefonokról elérhető volt a közvetlen városi vonal, így az asszony központos szerepe is megszűnt. A felvonó, az elektromos művek és a telexgép karbantartói csak felügyelettel dolgozhattak. A korábbi biztonsági felelös - a hatáskörök ismeretében Kristóf István (fedőneve „Gara”) - csak a hivatali munkaidő leteltével végezhette munkáját a biztonsági körletben, annak ugyanis az átépítés előtt erősen átjáróház jellege volt. Perczel László, Kincses László, Horváth Sándor és neje, Major Sándor (fedőneve „Bárdosi Géza” ${ }^{26}$ első beosztott tanácsos, Kun Tibor sajtóattasé, valamint Jankovics biztosan tudtak tevékenységéről. A körletnek csak az egyik fala nézett az utca felé, optikailag tehát védhető volt, azonban a rezidens szerint a lehallgatás már nem volt kizárható. A spanyol elhárítás emberei általában éjél és hajnali három óra között szokták felhívni a követséget. Amikor Juhász egyszer rákérdezett, hogy a telefonáló miért hívja rendszeresen a követséget, azt a választ kapta, hogy a jelentkező a biztosítótársaság éjjeli őre, akit erre utasítottak. Ezt követően már ritkábban jelentkeztek. Juhász gépkocsival történő követést nem tapasztalt, de a szovjet kollégája is úgy vélte, hogy a spanyolok az informátori hálózat révén ellenőrzik a keleti blokk (kevésbé jelentős) országainak követségeit. ${ }^{27}$

\section{A társszervek operatív tapasztalatai}

Juhász Gábor az 1979. október 26-i bolgár nemzeti ünnep alkalmából rendezett fogadáson találkozott először a KGB rezidensével - Viktor Mihajlovics Filippovval ${ }^{28}$-, aki 1977 óta szolgált Madridban. Az orosz tiszt elmondta, hogy megérkezését követően a spanyol elhárítás - pontosabban a Comisaria General de Información (a rendőrség hírszerzési szolgálata), ugyanis a CESID (Centro de Información de la Defensa, Védelmi Hírszerzési Központ), a legfőbb titkosszolgálati szerv nem rendelkezik müveleti képességgel ${ }^{29}$ - gépkocsival követte a külképviseleti szerveik munkatársait, amely fedetten, másszor nyílt és erőszakos módszerekkel zajlott egészen 1979 elejéig. A szovjet kolónia tagjait ezt követően inkább

26 ÁBTL - 3. 2. 1 - Bt - 2508 - „Bárdosi Géza” (Major Sándor). Évkör: 1953 - 1986. 152 oldal.

27 ÁBTL - 3. $2.5-$ O -8 - 562/1/2 - 15 - OD - 4896 - „Mediterrán” - Spanyolországi Magyar Kolónia Op. Védelme - 3/1-4/1980. 2-nek. - Dér Elvtársnak. Budapest. - Tárgy: nagykövetség és kereskedelmi kirendeltség biztonsági helyzete. - Madrid, 1980. III. 6. 33-38.

${ }_{28}$ Christopher Andrew - Vaszilij Mitrohin: A Mitrohin-archívum. A KGB otthon és nyugaton. Budapest, Talentum, 2000. 319 .

29 Andrea Gimenez-Salinas: The Spanish Intelligence Services. In Jean-Paul Brodeur - Peter Gill - Denis Töllborg (szerk.): Democracy, Law and Security. London, Routledge, 2016. 66-76. 
az előfordulási helyeiken - üzletek, éttermek, cukrászdák, fodrász, lakóhely - vonta megfigyelés alá a biztonsági szolgálat, ugyanakkor általános volt a külső helyszínen található szolgálati lakásokba történő behatolás. A rezidens valószínűsítette, hogy az irodákban és a diplomaták lakóhelyén lehallgatóberendezések vannak, amelyeket a rezidentúra megfelelő eszközök híján nem tudott felderíteni. Juhász ekkor ismertette a társszerv helyi vezetőjével, hogy amikor május elején a nagykövettel és egy másik diplomatával a Retiro Parkban folytatott megbeszéléseket, folyamatos figyelést tapasztalt. A KGB-tiszt is ugyanerről számolt be, azzal a kiegészítéssel, hogy a Retiro Park mellett a Casa de Campo (népliget) területén is állandó megfigyelőegységek találhatók, amelyek szúrópróbaszerü ellenőrzést hajtanak végre. Juhász sem zárta ki az MNK nagykövetségének lehallgatását, ezért a titkos ügyek tárgyalására mindig házon kívül kerülhetett csak sor. A szovjet rezidens és az MNK nagykövetségének biztonsági tisztje végül megállapodott, hogy tapasztalatcsere végett havonta egyszer találkoznak, ugyanakkor a vészhelyzeti jelzést is kidolgozták. ${ }^{30} 1980$ februárjában Filippov átadta az általuk azonosított 20 jármü típusát, színét és forgalmi rendszámát. ${ }^{31}$ A spanyol figyelőszolgálat jellemző módon legtöbbször a hazai gyártmányú SEAT márkájú gépkocsikat használta. Az egyetlen 850-es fehér színü volt M 545137 rendszámmal. A hat darab SEAT 124-esből három fehér - az M 6761 AE, az M 2161 és az M 2942 -, kettő bézs - M 4132 AK és M 8894 AN -, valamint egy - az M 6129 T rendszámú - gépkocsi kék színü volt. Az M 0753 AM forgalmi rendszámú SEAT 127-es sárga színü volt, a másik három - az M 2549 AS, az M 4222 BL és az M 505083 - pedig fehér. A nagyobb teljesítményű figyelőkocsik sorában az M 5200 O és az M 0121 B forgalmi rendszámú SEAT 1430 (a 124-es sportváltozata), valamint az M 494144 forgalmi rendszámú SEAT 1500-as tünt fel. A spanyol elhárítás ugyanakkor francia gyártmányú jármüvekkel is dolgozott. Az öt SIMCA közül a zöld színü - rendszáma M 1261 AS - típusának azonosítása nem járt sikerrel, míg a két 1000-es SIMCA - forgalmi rendszám szerint az M 2848 H és az M 5838 AD - szürke volt. Ehhez még egy bézs színű 1100-as modell - forgalmi rendszáma M 6328 - és egy fehér 1200-as - forgalmi rendszáma M 8472 AK - társult. Mindezen túl két Renault 12-es, egy sárga - M 3301 AP - és egy kék - M 1139 V - szerepelt a szovjet rezidens listáján. ${ }^{32} 1980$ júliusában a szovjet nagykövetségi rádiófigyelö bemérte a spanyol figyelőszolgálat kommunikációját. Az első két alkalommal a művelet résztvevői nyíltan tájékoztatták egymást a megfigyelt személyek mozgásáról, az említett utcanevek a Bravo Murillo, Morato, Dea Bermudez által határolt körzetre utaltak. A biztonsági szolgálat gyalogosan, a párhuzamos követési módszerrel dolgozott. A továbbiakban kódolt üzeneteket váltottak egymással. A figyelők július 1-jén és 28-án déli 12 óra és 14 óra között, július 3-án este hattól kilencig, miközben 7-én, 9-é, 10-én, 24-én és 31-én 16 órától 19 óráig, július 18-án 12 óra 45 perctől 17 óráig tevékenykedtek. A KGB-rezidentúra ezen időpontokban

30 ÁBTL - 3. 2.5 - O - 8 - 562/1/2 - 15 - OD - 4896 - „Mediterrán” - Spanyolországi Magyar Kolónia Op. Védelme - 6/2-4/1979. sz. jelentés. 2-nek. - Dér Elvtársnak. Budapest. - Tárgy: találkozó a szovjet rezidenssel. - Madrid, 1979. X. 5. 38-40.

31 ÁBTL - 3. 2.5 - O - 8 - 562/1/2 - 15 - OD - 4896 - „Mediterrán” - Spanyolországi Magyar Kolónia Op. Védelme - 2/1-4/1980. sz. jelentés. 2-nek. - Dér Elvtársnak. Budapest. - Tárgy: a szovjet nagykövetség helyzete. - Madrid, 1980. II. 15. 48 .

32 ÁBTL - 3. 2.5 - O - 8 - 562/1/2 - 15 - OD - 4896 - „Mediterrán” - Spanyolországi Magyar Kolónia Op. Védelme - 3/4-4/1980. sz. jelentés. 2-nek. - Dér Elvtársnak. Budapest. - Tárgy: spanyol elhárítás külső figyelése. - Madrid, 1980. III. 6.46 
nem hajtott végre operatív akciót, így az elhárítás nem őket tartotta szemmel. Jászai ez idő tájt Budapesten tartózkodott, saját tapasztalatai nem voltak. Megítélése szerint a Madridi Konferenciára készülődött a spanyol biztonsági szolgálat, amivel az orosz rezidens is egyetértett. ${ }^{33} 1982$ novemberében a kubai követség egyik diplomatája is jelezte Jászainak, hogy a spanyol elhárítás a bejáratukat rejtett helyről fotózza, ugyanakkor munkatársaikat rendszeresen ellenőrzés alá vonja. A kubai diplomata tapasztalatai szerint figyelőbrigádok rejtett fotótechnikai eszközöket is használtak. ${ }^{34}$ Ahogy Spanyolország 1982-ben csatlakozott a NATO-hoz, ${ }^{35}$ a keleti blokk hírszerző szerveinek müködési feltételei is nehezebbé váltak. Az MNK nagykövetségét ez láthatóan nem érintette, tudniillik 1984 első felében Markó József, az új biztonsági tiszt, Juhászhoz hasonlóan nem tudott személye ellen irányuló figyelésről beszámolni, azonban egy, a Varsói Szerződés tagországainak diplomatái részvételével a bolgár nagykövetségen tartott értekezlet után látta, ahogy a szovjet résztvevőt a spanyol rendőrség három autóval kísérte. Az orosz hírszerzőtiszt később elmondta, hogy az utolsó nagyobb, az ETA által elkövetett terrorakciót követően a figyelés megszünt, mivel az elhárítás átcsoportosította erőit. ${ }^{36}$

\section{Az átállás}

1979. november 17-én Soltész Judit, a kereskedelmi kirendeltség 32 éves titkárnője, aki 1974-től teljesített szolgálatot a spanyol fövárosban, arról tájékoztatta Gazdagot - Gazdag Ervint, aki 1974-től 1979-ig volt a madridi kereskedelmi kirendeltség vezetöje ${ }^{37}$-, hogy kiküldetése lejártával nem kíván visszatérni Magyarországra. A munkatársai szerint Soltész döntésében a szülők válása, valamint a korábbi fönökének ismételt megjelenése játszotta a fö szerepet. ${ }^{38}$ Tóth Vilmost, aki 1971 és 1975 között kereskedelmi titkár volt Madridban, a BND (Bundesnachrichtendienst, Szövetségi Hírszolgálat, az NSZK hírszerzés) ${ }^{39}$ 1974-ben megpróbálta beszervezni, ezért egy sikertelen játszma után hazarendelték. ${ }^{40}$ Soltész Judit ezt követően magába zárkózott, csak a legfontosabb eseményeken vett részt. Miután Tóth a megelőző héten turistaként Spanyolországba érkezett, egykori titkárnőjének hangulata is sokat javult. Igaz, mások előtt azt hangsúlyozta: nagyon nem esett jól, hogy Tóth búcsú nélkül ment el. A hazatérése előtti napon még Gazdaggal és az utódjául kijelölt Forgó Katalinnal személyesen is elköszönt Kincses László nagykövettől, de amikor Bleuer István kereskedelmi titkár (fedőneve „Laborf”) ${ }^{41} 17$-én délután kettőkor fel akarta venni, hogy ki-

\footnotetext{
3 ÁBTL - 3. 2.5 - O - 8 - 562/1/2 - 15 - OD - 4896 - „Mediterrán” - Spanyolországi Magyar Kolónia Op. Védelme - Belügyminisztérium III/I-2 Osztálya 536/80 - Feljegyzés. Budapest, 1980. VIII. 15. 50.

34 ÁBTL - 3. 2. 5 - O - 8 - 562/1/2 - 15 - OD - 4896 - „Mediterrán” - Spanyolországi Magyar Kolónia Op. Védelme - 11/4-3/1982. sz. jelentés. 2-nek. - Tárgy: A spanyol elhárítás. - Madrid, 1982. XI. 18. 73.

35 Asqui Jorge Kristóf: A spanyol NATO-csatlakozás: a demokrácia védelmi pilléréhez vezető hosszú út. Hadtudomány, 27. (2017) 1-2. 138-148.

36 ÁBTL - 3. 2.5 - O - 8 - 562/1/2 - 15 - OD - 4896 - „Mediterrán” - Spanyolországi Magyar Kolónia Op. Védelme - 1/12-2/1984. sz. jelentés. 3-nak is! - Tárgy: Madridi operatív helyzetről. - Madrid, 1984. II. 14. $171-172$.

37 ÁBTL - 3. 2. 1 - Bt - 1899 - „Gyömröi”(Gazdag Ervin). - Évkör: 1974-1980.

38 ÁBTL - 3. 2. 5 - O - 8 - 562/1 - 15 - OD - 4896 - „Mediterrán” - Spanyolországi Magyar Kolónia Op. Védelme - 7/5-4/1979. 2-nek. 7-nek - Dér Elvtársnak! Budapest. - Tárgy: A Soltész Judit ügye. - Madrid, 1979. XI. 17. 15.

39 Nigel West: Historical Dictionary of International Intelligence. New Delhi, Pentagon Press, 2010. 41.

40 ÁBTL - 3. 2. 4 - K- 2889 - „Tüskevári” (Tóth Vilmos). Évkör: 1966-1979. 124 oldal.

41 ÁBTL - 3. 2. 1 - Bt - 1900/2 - „Laborf” (Bleuer István). - Évkör: 1975-1980.
} 
vigye a repülőtérre, csak a Gazdagnak írt levelet találta az ajtón. Kincses azt javasolta, hogy Kun Tibor sajtóattasé és Dalmadi György gépkocsivezető próbáljon bejutni Soltész lakásába. A nő postaládájában hagyott kulcs a kirendeltségi irodákhoz tartozott, míg az Infante Mercedes 92. szám alatti ház portása közölte, hogy nem tudja a nagykövetség munkatársait beengedni a lakásba. Kincses végül engedélyezte, hogy a rendőrséghez forduljanak, de a portás végül megtalálta a lakáskulcsot a szekrényben. Soltész rendet hagyott maga után, névre szólóan borítékolta a különböző iratokat, amelyeket vissza akart juttatni. ${ }^{42}$ A titkárnő pár nappal döntése előtt ugyan találkozott egykori fönökével, majd nem sokkal később kiderült, Tóth Vilmos és családja sem óhajt hazatérni. ${ }^{43}$ Amikor 17 -én a kora délutáni órákban Soltész Judit hazatelefonált édesanyjának, távozását azzal indokolta, hogy spanyol férfiba szerelmes. ${ }^{44}$ A kirendeltség titkárnőjével Horváth Sándor és felesége az 1981. évi könyvvásáron találkozott legközelebb. Soltész nem tért ki előlük, sőt, őszintén beszámolt édesapja haláláról és vőlegényéről. Igaz, pontos címéről és munkahelyéről nem esett szó. Amikor elköszönt, Horváth észrevette, hogy Soltész úgy viselkedik, mintha ismerné azt a közelében lévő fiatalembert, aki legyezőket árusított. A rezidens arra szólította fel a biztonságtechnikai felelőst, hogy a legközelebbi alkalommal próbáljon rákérdezni Soltész tartózkodási és munkavállalási engedélyére és életkörülményeire. ${ }^{45} \mathrm{~A}$ kirendeltség korábbi titkárnője 1981 októberében megjelent a hazatérő sajtóattasé búcsúztatóján, amelyet az 1920-as évek óta Spanyolországban élő Fisch családnál tartottak. ${ }^{46}$ Soltészt 1982. június 9-i időponttal hagyatéki tárgyalásra idézték Budapestre, ${ }^{47}$ az ügy folytatásáról és a nő további sorsáról azonban semmit sem tudunk.

\section{A provokátor}

Míg Soltész Judit esetében sokkal inkább a magánéleti konfliktus, mintsem a politikai meggyőződés játszott szerepet - ekkor 62 esztendős ${ }^{48}$ - Liszka Nándorról rövid időn belül kiderült, hogy játszmára törekszik a magyar külképviseleti szervekkel. Liszka 1980 márciusának első hetében felajánlotta szolgálatait Decker Gyula kirendeltségvezetőnek, aki viszont jelezte: a Chilével történő árucsere nem időszerű. Egy későbbi személyes találkozón viszont közölte Liszka Nándorral, hogy magánjellegü kérésével nyugodtan forduljon a nagykövetség konzuli ügyekben illetékes diplomatájához. ${ }^{49} \mathrm{Az}$ üzletember május 13-án

42 ÁBTL - 3. 2. 5 - O - 8 - 562/1 - 15 - OD - 4896 - „Mediterrán” - Spanyolországi Magyar Kolónia Op. Védelme - 7/5-4/1979. 2-nek. 7-nek - DÉR Elvtársnak! Budapest. - Tárgy: A Soltész Judit ügye. - Madrid, 1979. XI. 17. 15-17.

43 ÁBTL - 3. 2.5 - O - 8 - 562/1 - 15 - OD - 4896 - „Mediterrán” - Spanyolországi Magyar Kolónia Op. Védelme - Belügyminisztérium III/I-6. Osztály - 67/9-6883/79. - Tárgy: Soltész Judit ügye. - Feljegyzés. Budapest, 1979. XI. 21. 22.

44 ÁBTL - 3. 2.5 - O - 8 - 562/1 - 15 - OD - 4896 - „Mediterrán” - Spanyolországi Magyar Kolónia Op. Védelme - Belügyminisztérium III/I-6. Osztály - 67/9-7138/79. - Tárgy: Soltész Judit ügye. - Feljegyzés. Budapest, 1979. XI. 29. 21.

45 ÁBTL - 3. 2. 5 - O - 8 - 562/1 - 15 - OD - 4896 - „Mediterrán” - Spanyolországi Magyar Kolónia Op. Védelme - 8/2-2/1981. sz. jelentés. - Mecseki Elvtársnak! Budapest. - Tárgy: Soltész Judit ügye. - Madrid, 1981. VI. 23. 58.

46 ÁBTL - 3. 2. 5 - O - 8 - 562/1 - 15 - OD - 4896 - „Mediterrán” - Spanyolországi Magyar Kolónia Op. Védelme - Belügyminisztérium III/I-2. Osztály - 1148/81. - Tárgy: 7152. sz. madridi táv-ról. - Feljegyzés. Budapest, 1981. X. 8. 102.

47 ÁBTL - 3. 2. 5 - O - 8 - 562/1 - 15 - OD - 4896 - „Mediterrán” - Spanyolországi Magyar Kolónia Op. Védelme - Belügyminisztérium III/I-2. Osztály - 1467/81. - Tárgy: 8951. sz. madridi táv-ról. - Feljegyzés. Budapest, 1981. XII. 2. 122.

48 Gefangenen des Arbeitslagers Recsk. [online], Forrás: recskiszovetseg.hu [2020. 08. 31.].

49 ÁBTL - 3. 2. 5 - O - 8 - 562/1 - 15 - OD - 4896 - „Mediterrán” - Spanyolországi Magyar Kolónia Op. Védelme - 4/3-4/1980. 2-nek. - Dér Elvtársnak! Budapest. - Tárgy: Liszka Nándor ügyében. - Madrid, 1980. III. 26. 42. 
17 órakor felhívta Juhász Péter II. o. titkárt, akitől meghallgatást kért a felesége ügyében. A rezidens a kirendeltségvezetőt viszont igyekezett távol tartani, mivel az áprilisban többször is kitért Liszka elől, de másnap reggel fél kilenckor az ügyfél rendelkezésére állt. A kérelmező megmutatta felesége konzuli útlevelét, amelyet 1976 januárjában kapott kézhez az MNK konzuli kirendeltségétől. Liszka 1967 nyarán találkozott elöször Tóth Erzsébettel, aki turistaúton járt Svédországban, az ismeretségből végül házasság lett. 1973 óta Alicante-ban volt egy házuk - az évtized közepén már jelentős számú svéd nyugdíjas élt Spanyolországban ${ }^{50}-$ az asszony útlevele 1975 végén ott tünt el. A rezidens ekkor finoman jelezte, hogy a hosszabbítási kérelem benyújtásával októberig várhatnak. Liszka ekkor viszont egy másik ügyben is beszélni kívánt a diplomatával. Az üzletember, aki 1969-ben a Volt Magyar Politikai Foglyok Szövetségének svédországi szervezetét vezette, ${ }^{51}$ a Német Szövetségi Köztársaságban (NSZK) rész vállalt az ottani emigráció életében, megemlítette a Tollas csendőr szervezetet és a magyar gimnáziumot. Miközben elhatárolódott az ottani szélsőségesektől, megpendítette, hogy nyomás alatt van mindenki, aki a keleti blokkal kereskedik. Spanyolországban ilyet viszont nem tapasztalt, ezért jött munkaadójától olyan kérés, hogy lépjen kapcsolatba az MNK kereskedelmi képviseletével. Liszka elmondása szerint az 1950-es évek folyamán börtönben volt, 1955-ben egyedül neki jött össze a szökés, amivel a Szabad Európa Rádió és az Amerika Hangja is foglalkozott. (A valóságban Liszka Nándor Recsken töltötte büntetését, ám a szökésről szóló történet aligha hihető, mivel a Rákosi-rendszer leghírhedtebb munkatábora 1953. szeptember 23-án megszünt.) ${ }^{52}$ $\mathrm{Az}$ érdeklődő ezzel egy időben rákérdezett, hogy Juhász ismeri-e Kocziha [Miklós]-t a Belügyminisztériumból, mire Juhász rászólt, hogy az illető a Külügyminisztériumban dolgozik. (1980-ban Kocziha Miklós volt a KÜM Emigrációs Politikai Osztályának vezetője. $)^{53} \mathrm{Az}$ üzletember ugyanakkor arra kérte a diplomatát, hogy hívja fel a kereskedelmi kirendeltséget, mivel január óta nem tudott velük kapcsolatot teremteni. Forgó Katalin vette fel a telefont, aki óvatlanul egyből kapcsolta Róth János kereskedelmi titkárt. Az utóbbi végül elhárította az érdeklődést, mondván még mindig a válaszra vár a Liszka által felvetett ügyben. Juhász ekkor az üzletember tudtára adta, hogy más ügyfelekre való tekintettel nem foglalkozhat tovább vele. ${ }^{54} \mathrm{Az}$ üzletember és felesége 1980. november 18-án ismét felbukkant a madridi nagykövetségen. A látogatás oka az új útlevél kiállitása volt, amire a spanyol tartózkodási engedély bejegyzéséhez volt szükség. Juhász kiállította az okmányokat, amikor a házaspár furcsa kéréssel állt elő. Tóth Erzsébet számára a svéd belügyminisztérium megelőlegezte az állampolgárságot, de ehhez 1982. október 8-ig le kellett mondania magyar útleveléről. Amennyiben ehhez az MNK nem járul hozzá, az sem akadály, de a kérelmet meg kell mutatni. Az asszony mindezt azzal indokolta, hogy a svéd törvények értelmében állampolgárság nélkül nem örökölheti férje vagyonát és nem szerez nyugdíjjogosultságot.

50 Per Gustafson: Your Home in Spain: Residential Strategies in International Retirement Migration. In Michaela Benson - Karen O'Reilly (eds.): Lifestyle Migration. Expectations, Aspirations and Experience. London, Routledge, 2016. 69-87.

51 United States of America Congressional Record Proceedings and Debates of the 91st Congress First Sessions Volume 115 - Part 3. February 5, 1969 to February 21, 1969. (Pages 2775 to 4178) February 18, 1969. 3887.

52 Bank Barbara - Gyarmati György - Palasik Mária: „Állami titok”. Internáló-és kényszermunkatáborok Magyarországon 1945-1953. Budapest, Állambiztonsági Szolgálatok Történeti Levéltára - L’Harmattan, 2012. 55-56/110.

53 Baráth-Gecsényi (2015) i. m. 203.

54 ÁBTL - 3. 2. 5 - O - 8 - 562/1 - 15 - OD - 4896 - „Mediterrán” - Spanyolországi Magyar Kolónia Op. Védelme - 6/2-4/1980. sz. jelentés. - Dér Elvtársnak! Budapest. - Tárgy: Liszka Nándor ügye. - Madrid, 1980. V. 14. 29-30. 
Igaz, a magyar állampolgárságot sem akarta elveszíteni. Tóth Erzsébet annak örült volna a legjobban, ha az Elnöki Tanács nem járul hozzá az elbocsátáshoz, mert így a svédek nem hozhatják kényszerhelyzetbe. Juhász azonban jelezte, hogy kár volt új útlevelet kérni, mert az elbocsátással egy időben azt vissza kell adnia. Liszka Nándor pedig arról érdeklődött, hogy szerepel-e a beutazást tiltó listán, vagy amennyiben hazalátogatnak, visszaengedik-e őket nyugatra. Juhász közölte, hogy 90 napig minden további nélkül Magyarországon tartózkodhat, a hazatelepülést azonban külön kell kérvényezni, és megélhetéséről magának kell gondoskodni. Tóth Erzsébet esetében pedig csak annyit füzött hozzá, hogy ha nem követ el bűncselekményt, akkor semmi bántódása nem eshet. Liszka ekkor megemlítette, hogy jól ismeri Győri Tamás volt stockholmi magyar konzult. Ezt követően arról érdeklődött, hogy Juhász ismeri-e Zsiga Árpádot a bécsi magyar nagykövetségről, illetve Fürjes Jenőt, aki korábban ugyanott szolgált. A rezidens rábólintott, hogy Zsiga ismerősen hangzik, bár nem tudja archoz kötni, a másik nem. Liszka erre annyit mondott, hogy Fürjes már nyugdíjas lehet, hiszen hozzá hasonlóan elmúlt 64 éves. ${ }^{55}$ A valóságban Fürjes János, aki 1920-ban született, 1972-ben vonult vissza a szolgálatból, Zsiga Árpád pedig 1971-ben tért vissza Bécsből, hogy előbbitől átvegye a III/I-7. (Emigrációs) Osztály vezetését. ${ }^{56} \mathrm{~A}$ rendőr alezredes 1978-tól 1982-ig a bécsi förezidentúra parancsnokaként irányította az emigráció elleni műveleteket, miközben fedőállása szerint a Külügyminisztérium Konzuli Osztályának föelőadója volt. ${ }^{57}$ 1980. december 9-én a III/I-2-es Osztály megerősítette, hogy Liszka provokátor, akinek személyével nem kíván foglalkozni. Juhász csak ügyfélként tárgyalhatott vele. ${ }^{58}$ Bár a másik oldal forrásai nem állnak rendelkezésre, nagyon valószínü, hogy Liszka a BND megbízásából azt próbálta felmérni, hogy a madridi magyar nagykövetség biztonsági tisztje milyen szerepet játszik a külföldi magyar diaszpóra feltérképezésében.

\section{A betörés}

1981. március 14-én az esti órákban ismeretlen tettesek behatoltak Kovács Imre MALÉV igazgató lakásába, ahol feldúlták az egyik háló- és a dolgozószobát. A katonai társszerv rezidense a házkutatás módszeréből arra következtetett, hogy megfélemlítési akcióról van szó. ${ }^{59} \mathrm{~A}$ Madridban állomásozó rangidős KGB-tiszt úgy vélte, hogy egyértelmüen a spanyol biztonsági szolgálat áll az ügy mögött, amely a február 23 -i elvetélt puccs nyomán ${ }^{60} \mathrm{kapott}$ bírálatok élét a szocialista országok képviseleteivel szemben folytatott intézkedésekkel próbálja tompítani. A kiutazó szovjet küldöttségeket az elhárítás szoros megfigyelés alá von-

55 ÁBTL - 3. 2.5 - O - 8 - 562/1 - 15 - OD - 4896 - „Mediterrán” - Spanyolországi Magyar Kolónia Op. Védelme - 12/3-4/1980. sz. jelentés. - DÉR Elvtársnak! Budapest. - Tárgy: dr. Liszka Nándor. - Madrid, 1980. XII. 9. $27-28$.

56 Pál István - Szilágyi Ágnes Judit: „... kisebb-nagyobb ütést mértünk a jobboldali emigrációra...”, avagy az „Odier”-ügy. Kóródy Tibor hazatérése az argentínai emigrációból. Múltunk, 63. (2018), 4. 29.

57 ÁBTL Archontológia 938/941 - Zsiga Árpád. [online], Forrás: abtl.hu [2020. 09.01.].

58 ÁBTL - 3. 2. 5 - O - 8 - 562/1 - 15 - OD - 4896 - „Mediterrán” - Spanyolországi Magyar Kolónia Op. Védelme - 3/4-2/80. sz. Utasítás! - Jászai Elvtársnak! Madrid. - Tárgy: Liszka Nándor ügye. - Budapest, 1980. XII. 9. 45.

59 ÁBTL - 3. 2. 5 - O - 8 - 562/1 - 15 - OD - 4896 - „Mediterrán” - Spanyolországi Magyar Kolónia Op. Védelme - BM III/I-2 Osztály. - Tárgy: 39. sz. madridi táviratról Feljegyzés. - Budapest, 1981. III. 19. 50.

60 Bod De Graaff - James M. Nyce - Chelsea Locke (eds.): The Handbook of European Intelligence Cultures. New York, Rowman \& Littlefield, 2016. 359-365. 
ta, rendszeresen zaklatta a vállalati képviselőket, és még egy diplomatát is kiutasítottak. ${ }^{61}$ 1981. augusztus 31-én Lehel Miklós (fedőneve „Petres Géza”) ${ }^{62}$ házfelügyelöje felhívta a nagykövetséget, hogy az MTI-tudósító lakásának konyhai bejáratát feltörték. A katonai attasé és Horváth Sándor kiment a helyszínre, de mint kiderült, semmit nem vittek el, csak néhány fiók volt nyitva. A társszerv rezidense szerint megfélemlítésről volt szó. Lehel Juhászt csak három hét elteltével informálta, mondván a rangidős BM tiszt már úgyis tud az esetről. Lehel ezt csak annyiban egészítette ki, hogy egy baloldali lapoknak dolgozó portugál kollégája nem sokkal korábban ugyanígy járt. ${ }^{63}$

\section{Az ,üzleti” ajánlat}

1981 decemberében Wlado Markovic jugoszláv labdarúgó-menedzser bemutatta „Szilárd” fedőnevü titkos munkatársnak - itt feltehetően Éliás István kereskedelmi titkárról van szó - a 40 év körüli Angel Perezt. Az utóbbi vezető beosztást töltött be a Spanyol Televíziónál, azonban Castedo elnök eltávolította, mivel túlságosan is jobboldalinak tekintette. Markovic úgy tudta, hogy Perez Martin Villa, az akkori kormányfö politikai helyettese, titkáraként dolgozott. Perez állítása szerint Robles Piquer, a TVE újonnan kinevezett elnöke, ugyan visszahívta, de ettől húzódozott, mondván az új vezetők többségét szélsőjobboldalinak tekinti. Éliás időközben rájött, hogy Perez üzletkötésekkel egészíti ki jövedelmét, a harmadik találkozón mégis meglepetésként érte, hogy uránkoncentrátum eladására tett ajánlatot. Perez hamarosan visszakozott, hogy az urán kényes áru, miközben nem volt meggyőződve róla, hogy az eladó egy szocialista országgal is hajlandó üzletet kötni. A december 9-i munkaebéden ugyanakkor 1-1,5\%-os jutalékra tett ajánlatot partnerének valamennyi, az ő közreműködésével létrejött borvásárlásért. Perez erőltette az ügyet, Éliás azonban nem kötelezte el magát. Perez több olyan értesülést adott, amely beteljesült. Jászai Perez tanulmányozására szólította fel a titkos munkatársat ${ }^{64}$ amire a Központ a kapcsolat történetének teljes bemutatását kérte, mivel a gyorsan visszavont ajánlat és a jutalék ígérete arra utalt, hogy Perez Éliás kereskedelmi titkár személyét tanulmányozza. ${ }^{65}$

\section{Utószó}

A fenti ügy folyatásáról nincs tudomásunk, mivel a „Mediterrán” fedőnevü dosszié második kötete, amely az 1985 és 1990 közötti időszakot tárgyalja, nem található az Állambiztonsági Szolgálatok Történeti Levéltára (ÁBTL) őrizetében. Az utóbbit a III/I. Csoportfönökség jogutóda, az Információs Hivatal (IH) feltehetően azért nem tette kutathatóvá, mert az veszélybe sodorna több olyan személyt, aki még most is a hálózathoz tartozik, vagy csak jóval

${ }_{61}$ ÁBTL - 3. 2.5 - O - 8 - 562/1 - 15 - OD - 4896 - „Mediterrán” - Spanyolországi Magyar Kolónia Op. Védelme - BM III/I-2 Osztály. - Tárgy: 46. sz. madridi táviratról Feljegyzés. - Budapest, 1981. III. 18. 51.

62 ÁBTL - 3. 2. 1 - Bt - 2262 - „Petres Géza” (Lehel Miklós). - Évkör: 1966-1984. 169 oldal.

${ }^{63}$ ÁBTL - 3. 2.5 - O - 8 - 562/1 - 15 - OD - 4896 - „Mediterrán” - Spanyolországi Magyar Kolónia Op. Védelme - 10/1-2/1981 sz. jelentés 3-nak - Tárgy: behatolás Petress lakásába. - Madrid, 1981. IX. 21. 62.

${ }^{64}$ ÁBTL - 3. 2. 5 - O - 8 - 562/1/2 - 15 - OD - 4896 - „Mediterrán” - Spanyolországi Magyar Kolónia Op. Védelme - 18/14-3/1981. sz. jelentés. - Dér Elvtársnak! Budapest. - Tárgy: Angel Perez ügye. - Madrid, 1981. XII. 14. 57.

65 ÁBTL - 3. 2. 5 - O - 8 - 562/1/2 - 15 - OD - 4896 - „Mediterrán” - Spanyolországi Magyar Kolónia Op. Védelme - 1/1-2/82. sz. Utasítás! - Jászai Elvtársnak! Madrid. - Tárgy: Angel Perez ügye. - Budapest, 1982. I. 12. 58. 
a rendszerváltást követően zárták ki őket a hálózatból. Az viszont szinte biztos, hogy nem a Spanyol Királyság alattvalóiról, hanem olyan országok állampolgárairól van szó, amelyek instabilitása az európai kontinens biztonságára nézve komoly fenyegetést jelent. Mennyire volt eredményes a madridi magyar rezidentúra tevékenysége? A diplomáciai fedéssel müködő hírszerzőállomás - amelynek létezése a fogadó ország előtt ismert ${ }^{66}$ - feladata az adott államra vonatkozó titkos információk megszerzése titkos (operatív) eszközökkel és módszerekkel a politikai, katonai, gazdasági, tudományos stb. hírigények alapján. ${ }^{67}$ Ezzel szemben a III/I. Csoportfőnökség Spanyolországban mindössze a kolónia, azaz a hivatalos kiküldetésben lévő magyar állampolgárok közössége, védelmére vállalkozott. A feladat teljesítése a vizsgált időszakban felemás eredménnyel végződött, amennyiben - mindenekelőtt magánéleti okokból - két „átállás” is történt. (A titkárnő ügyéről részletesen szóltunk, a korábbi sajtóattasé személyéről az esetleges jogi következmények miatt nem.) Igaz, ezzel egy időben a provokációkat a rezidens és a titkos munkatársak sikeresen elhárították. Mindazonáltal, nem lehet szó nélkül hagyni, hogy Liszka Nándor kivételével a többi próbálkozó meglehetősen primitív, mondvacsinált ajánlatokkal huzakodott elő, amely a magyar hírszerzés washingtoni és londoni rezidentúráján a provokátorok által az 1950-es, 1960-as években előadott trükköket idézte. Tudomásunk szerint a nyugati hírszerzőszervek egyike sem hajtott végre sikeres beszervezést a Madridban külszolgálatot teljesítők közül, ugyanakkor a nyelvi akadályok és az esetleges rokoni kötődések hiányában a spanyol rendőri szervekbe és a biztonsági szolgálatba történő beépülés sem hozott eredményeket. Az utóbbi elvárás magyar részről alapjában véve irreális volt, az ellenséges titkosszolgálatokba való behatolásra a KGB-n kívül leginkább a keletnémet hírszerzés, a HVA (Hauptverwaltung Aufklärung, Külső Felderítési Főigazgatóság) szolgálhatott példákkal. ${ }^{68}$

\section{FELHASZNÁLT IRODALOM}

Anderle Ádám: Bevezetés. A magyar-spanyol diplomáciai kapcsolatok történetéhez. Külügyi Szemle, 9. (2010), 3. 5-13.

Andrew, Christopher - Vaszilij Mitrohin: A Mitrohin-archívum. A KGB otthon és nyugaton. Budapest, Talentum, 2000.

Asqui Jorge Kristóf: A spanyol NATO-csatlakozás: a demokrácia védelmi pilléréhez vezető hosszú út. Hadtudomány, 27. (2017), 1-2. 138-148.

ÁBTL Archontológia 938/941 - Zsiga Árpád. [online], Forrás: abtl.hu [2020. 09. 01.]

Bank Barbara - Gyarmati György - Palasik Mária: „Állami titok”. Internáló-és kényszermunkatáborok Magyarországon 1945-1953. Budapest, Állambiztonsági Szolgálatok Történeti Levéltára - L’Harmattan, 2012.

Baráth Magdolna - Gecsényi Lajos (szerk.): Főkonzulok, követek és nagykövetek. MTA Bölcsészettudományi Kutatóközpont Történettudományi Intézet, 2015.

Eiroa, Matilde: A múltbeli kapcsolatoktól a jelenkori követelményekig. A spanyol-magyar kapcsolatok helyreállításának folyamata. Múltunk, 21. (2009), 1. sz. 89-98.

66 Állambiztonsági Értelmező Kéziszótár (1970) i. m. 59.

67 Állambiztonsági Értelmező Kéziszótár (1970) i. m. 41.

68 Benjamin B. Fischer: Brudenorgane: The Soviet Origins of East German Intelligence. In Uwe Spiekermann (ed.): The Stasi at Home and Abroad. Domestic Order and Foreign Intelligence. Washington D.C., German Historical Institute, 2014. 160-170. 
Fischer, Benjamin B.: Brudenorgane: The Soviet Origins of East German Intelligence. In Uwe Spiekermann (ed.): The Stasi at Home and Abroad. Domestic Order and Foreign Intelligence. Washington D.C., German Historical Institute, 2014. 160-170.

Fischer Ferenc: A megosztott világ. A Kelet-Nyugat, Észak-Dél nemzetközi kapcsolatok fö vonásai (1941-1991). Budapest, IKVA, 1993.

Gefangenen des Arbeitslagers Recsk. [online], Forrás:recskiszovetseg.hu [2020. 08. 31.]

Gimenez-Salinas, Andrea: The Spanish Intelligence Services. In Jean-Paul Brodeur - Peter Gill - Denis Töllborg (eds.): Democracy, Law and Security. London, Routledge, 2016.

Graaff, Bod de- James M. Nyce - Chelsea Locke (eds.): The Handbook of European Intelligence Cultures. New York, Rowman \& Littlefield, 2016.

Gustafson, Per: Your Home in Spain: Residential Strategies in International Retirement Migration. In Michaela Benson - Karen O’Reilly (eds.): Lifestyle Migration. Expectations, Aspirations and Experience. London, Routledge, 2016.

M. Szebeni Géza: A magyar-spanyol diplomáciai kapcsolatok újrakötése. Grotius, 5. (2011), 1. 1-14.

Pál István - Szilágyi Ágnes Judit: „... kisebb-nagyobb ütést mértünk a jobboldali emigrációra..., avagy az „Odier”ügy. Kóródy Tibor hazatérése az argentínai emigrációból. Múltunk, 63. (2018), 4. 1-33.

Tóth Eszter: A politikai és gazdasági hírszerzés szervezettörténete 1945-1990. In Cseh Gergő Bendegúz - Okváth Imre (szerk.): A megtorlás szervezete. A politikai rendőrség újjászervezése és müködése 1956-1962. Budapest, Állambiztonsági Szolgálatok Történeti Levéltára - L’Harmattan, 2013. 432-433.

West, Nigel: Historical Dictionary of International Intelligence. New Delhi, Pentagon Press, 2010.

\section{Levéltári források}

Állambiztonsági Szolgálatok Történeti Levéltára (ÁBTL) - 3. 2.5 - O - 8 - 562/1/2 - 15 - OD - 4896 - „Med iterrán” - Spanyolországi Magyar Kolónia Op. Védelme - Tárgy: Madridi külképviseletünkkel kapcsolatos megbeszélés. - Feljegyzés. Budapest, 1979. IX. 12.

ÁBTL - 3. 2.5 - O - 8 - 562/1 - 15 - OD - 4896 - „Mediterrán” - Spanyolországi Magyar Kolónia Op. Védelme - 1/1-2/79. sz. Utasítás! - Jászai elvtársnak! Madrid. - Tárgy: A hírszerzőpontok 2-es Vonal támadólagos munkájával kapcsolatos feladatok. - Budapest, 1979. VII. 13.

ÁBTL - 3. 2.5 - O - 8 - 562/1 - 15 - OD - 4896 - „Mediterrán” - Spanyolországi Magyar Kolónia Op. Védelme - 2/1-2/80. sz. Utasítás! - Jászai elvtársnak! Madrid. - Tárgy: A hírszerzőpontok 2-es vonalon folytatott tevékenységének felmérése, a speciális szolgálatok elleni munka erősítésének feladatai. - Budapest, 1980. IX. 16.

ÁBTL - 3. 2.5 - O - 8 - 562/1 - 15 - OD - 4896 - „Mediterrán” - Spanyolországi Magyar Kolónia Op. Védelme - 2/2-2/1980. sz. jelentés melléklete. - Madrid, 1980. II. 15.

ÁBTL - 3. 2. 5 - O - 8 - 562/1 - 15 - OD - 4896 - „Mediterrán” - Spanyolországi Magyar Kolónia Op. Védelme - 7/2-2/1981. sz. jelentés. - Mecseki elvtársnak Budapest - Tárgy: diplomata kapcsolatok. - Madrid, 1981. V. 20.

ÁBTL - 3. 2.5 - O - 8 - 562/1 - 15 - OD - 4896 - „Mediterrán” - Spanyolországi Magyar Kolónia Op. Védelme - Belügyminisztérium III/I-2. Osztály - Tárgy: Juhász Péter elvtárs beszámoltatásáról - Jelentés. Budapest, 1982. IX. 15.

ÁBTL - 3. 2.5 - O - 8 - 562/1 - 15 - OD - 4896 - „Mediterrán” - Spanyolországi Magyar Kolónia Op. Védelme - Belügyminisztérium III/I. Csoportfőnökség 4. Osztály. - Tárgy: Madridi és lisszaboni nagykövetségen végrehajtott technikai elhárításról. Jelentés. Budapest, 1983. X. 14.

ÁBTL - 3. 2.5 - O - 8 - 562/1/2 - 15 - OD - 4896 - „Mediterrán” - Spanyolországi Magyar Kolónia Op. Védelme - Belügyminisztérium III/I-11 Osztály - 67/81-1681/76 - Budapest, 1976. XII. 2.

ÁBTL - 3. 2.5 - O - 8 - 562/1/2 - 15 - OD - 4896 - „Mediterrán” - Spanyolországi Magyar Kolónia Op. Védelme - 1/9/1976. 11-nek: Információs jelentés. - Tárgy: A fogadó ország titkosszolgálati szerveinek ellenőrzési módszereiről és a külképviselet biztonsági helyzetéről. - Madrid, 1976. XII. 16.

ÁBTL - 3. 2.1 - Bt - 1792/1 - „Edina” (Fehér Józsefné Szalai Teréz) - Évkör: 1975-1979. 
ÁBTL - 3. 2.1 - Bt - 2508 - „Bárdosi Géza”(Major Sándor). Évkör: 1953 - 1986. 152 oldal.

ÁBTL - 3. 2.5 - O - 8 - 562/1/2 - 15 - OD - 4896 - „Mediterrán” - Spanyolországi Magyar Kolónia Op. Véd elme - 3/1-4/1980. 2-nek. - Dér elvtársnak. Budapest. - Tárgy: nagykövetség és kereskedelmi kirendeltség biztonsági helyzete. - Madrid, 1980. III. 6.

ÁBTL - 3. 2.5 - O - 8 - 562/1/2 - 15 - OD - 4896 - „Mediterrán” - Spanyolországi Magyar Kolónia Op. Védelme - 6/2-4/1979. sz. jelentés. 2-nek. - Dér elvtársnak. Budapest. - Tárgy: találkozó a szovjet rezidenssel. - Madrid, 1979. X. 5.

ÁBTL - 3. 2.5 - O - 8 - 562/1/2 - 15 - OD - 4896 - „Mediterrán” - Spanyolországi Magyar Kolónia Op. Védelme - 2/1-4/1980. sz. jelentés. 2-nek. - Dér elvtársnak. Budapest. - Tárgy: a szovjet nagykövetség helyzete. - Madrid, 1980. II. 15.

ÁBTL - 3. 2.5 - O - 8 - 562/1/2 - 15 - OD - 4896 - „Mediterrán” - Spanyolországi Magyar Kolónia Op. Védelme - 1/12-2/1984. sz. jelentés. 3-nak is! - Tárgy: Madridi operatív helyzetről. - Madrid, 1984. II. 14.

ÁBTL - 3. 2.1 - Bt - 1899 - „Gyömrő””(Gazdag Ervin). - Évkör: 1974-1980.

ÁBTL - 3. 2. 5 - O - 8 - 562/1 - 15 - OD - 4896 - „Mediterrán” - Spanyolországi Magyar Kolónia Op. Védelme - 7/5-4/1979. 2-nek. 7-nek - Dér elvtársnak! Budapest. - Tárgy: A Soltész Judit ügye. - Madrid, 1979. XI. 17.

ÁBTL - 3. 2.4 - K- 2889 - „Tüskevári” (Tóth Vilmos). Évkör: 1966-1979. 124 oldal.

ÁBTL - 3. 2. 5 - O - 8 - 562/1 - 15 - OD - 4896 - „Mediterrán” - Spanyolországi Magyar Kolónia Op. Védelme - Belügyminisztérium III/I-6. Osztály - 67/9-6883/79. - Tárgy: Soltész Judit ügye. - Feljegyzés. Budapest, 1979. XI. 21.

ÁBTL - 3. 2. 5 - O - 8 - 562/1 - 15 - OD - 4896 - „Mediterrán” - Spanyolországi Magyar Kolónia Op. Védelme - Belügyminisztérium III/I-6. Osztály - 67/9-7138/79. - Tárgy: Soltész Judit ügye. - Feljegyzés. Budapest, 1979. XI. 29.

ÁBTL - 3. 2. 5 - O - 8 - 562/1 - 15 - OD - 4896 - „Mediterrán” - Spanyolországi Magyar Kolónia Op. Védelme - 8/2-2/1981. sz. jelentés. - Mecseki elvtársnak! Budapest. - Tárgy: Soltész Judit ügye. - Madrid, 1981. VI. 23.

ÁBTL - 3. 2. 5 - O - 8 - 562/1 - 15 - OD - 4896 - „Mediterrán” - Spanyolországi Magyar Kolónia Op. Védelme - Belügyminisztérium III/I-2. Osztály - 1148/81. - Tárgy: 7152. sz. madridi táv-ról. - Feljegyzés. Budapest, 1981. X. 8.

ÁBTL - 3. 2. 5 - O - 8 - 562/1 - 15 - OD - 4896 - „Mediterrán” - Spanyolországi Magyar Kolónia Op. Védelme - Belügyminisztérium III/I-2. Osztály - 1467/81. - Tárgy: 8951. sz. madridi táv-ról. - Feljegyzés. Budapest, 1981. XII. 2.

ÁBTL - 3. 2. 5 - O - 8 - 562/1 - 15 - OD - 4896 - „Mediterrán” - Spanyolországi Magyar Kolónia Op. Védelm e - 4/3-4/1980. 2-nek. - Dér elvtársnak! Budapest. - Tárgy: Liszka Nándor ügyében. - Madrid, 1980. III. 26.

ÁBTL - 3. 2. 5 - O - 8 - 562/1 - 15 - OD - 4896 - „Mediterrán” - Spanyolországi Magyar Kolónia Op. Védelme - 6/2-4/1980. sz. jelentés. - Dér elvtársnak! Budapest. - Tárgy: Liszka Nándor ügye. - Madrid, 1980. V. 14.

ÁBTL - 3. 2.5 - O - 8 - 562/1 - 15 - OD - 4896 - „Mediterrán” - Spanyolországi Magyar Kolónia Op. Védelme - 12/3-4/1980. sz. jelentés. - Dér elvtársnak! Budapest. - Tárgy: dr. Liszka Nándor. - Madrid, 1980. XII. 9.

ÁBTL - 3. 2. 5 - O - 8 - 562/1 - 15 - OD - 4896 - „Mediterrán” - Spanyolországi Magyar Kolónia Op. Védelme - 3/4-2/80. sz. Utasítás! - Jászai elvtársnak! Madrid. - Tárgy: Liszka Nándor ügye. - Budapest, 1980. XII. 9.

ÁBTL - 3. 2. 5 - O - 8 - 562/1 - 15 - OD - 4896 - „Mediterrán” - Spanyolországi Magyar Kolónia Op. Védelme - BM III/I-2 Osztály. - Tárgy: 39. sz. madridi táviratról Feljegyzés. - Budapest, 1981. III. 19.

ÁBTL - 3. 2. 5 - O - 8 - 562/1 - 15 - OD - 4896 - „Mediterrán” - Spanyolországi Magyar Kolónia Op. Védelme - BM III/I-2 Osztály. - Tárgy: 46. sz. madridi táviratról Feljegyzés. - Budapest, 1981. III. 18.

ÁBTL - 3. 2. 1 - Bt - 2262 - „Petres Géza” (Lehel Miklós). - Évkör: 1966-1984. 169 oldal.

ÁBTL - 3. 2. 5 - O - 8 - 562/1 - 15 - OD - 4896 - „Mediterrán” - Spanyolországi Magyar Kolónia Op. Védelme - 10/1-2/1981 sz. jelentés 3-nak - Tárgy: behatolás Petress lakásába. - Madrid, 1981. IX. 21. 
ÁBTL - 3. 2.5 - O - 8 - 562/1/2 - 15 - OD - 4896 - „Mediterrán” - Spanyolországi Magyar Kolónia Op. Védelme - 18/14-3/1981. sz. jelentés. - Dér elvtársnak! Budapest. - Tárgy: Angel Perez ügye. - Madrid, 1981. XII. 14.

ÁBTL - 3. 2.5 - O - 8 - 562/1/2 - 15 - OD - 4896 - „Mediterrán” - Spanyolországi Magyar Kolónia Op. Védelme - 1/1-2/82. sz. Utasítás! - Jászai elvtársnak! Madrid. - TÁRGY: Angel Perez ügye. - Budapest, 1982. I. 12.

\section{Egyéb forrás}

United States of America Congressional Record Proceedings and Debates of the $91^{\text {st }}$ Congress First Sessions Volume 115 - Part 3. February 5, 1969 to February 21, 1969. (Pages 2775 to 4178) 